\title{
Terre(ur): Reading the Landscape of Conspiracy in Balzac's Une ténébreuse affaire
}

\section{Rebecca Sugden}

This article draws on Carlo Ginzburg's conjectural paradigm to propose a re-evaluation of the dialectic between models of "surface" and "depth" reading in Balzac's Une ténébreuse affaire (1841). A tale of shadowy machinations that overlap to bewildering effect, the novel testifies to the semantic multiplicity of the term plot as bearing on the topographic, the narrative and the conspiratorial. Through close engagement with the venatic metaphoricity common to both Ginzburg's model and Balzac's proto-roman policier, this article argues that the conspiratorial landscape of Une ténébreuse affaire testifies to an anxiety born of the impossibility of grounding novelistic truth in a stable referent. The recurrent emphasis on the problematic materiality of the surface and its false depths belies Balzac's fraught relationship to the severed referentiality of his narrative. As illustration of a Balzacian poetics of conspiracy, Une ténébreuse affaire, it is suggested, ultimately points forward in literary history towards the Flaubertian aesthetic of platitude.

Felix, qui potuit rerum cognoscere causas.

\section{— Virgil, Georgics}

In his essay "Clues" (1989), Carlo Ginzburg retraces the genealogy of what he terms the conjectural or evidential paradigm back to the "storehouse of knowledge" of the hunter. ${ }^{\text {i }}$ This venatic expertise manifests itself in the practice of reconstructing "the shapes and movements of his invisible prey from tracks on the ground" (102), moving from the fragment to the totality. If Ginzburg's hunter possesses a form of knowledge that allows for the reconstitution of the form of an animal from the traces it leaves in its wake, he is also, first and foremost, a storyteller. He engages with a surface in its materiality to assemble the deeper story that might be summarized in its most rudimentary terms as: "someone passed this way." Ginzburg goes 
on to speculate that "the actual idea of narration [.. . ] may have originated in a hunting society, relating the experience of deciphering tracks [...] The hunter would have been the first to "tell a story' because he alone was able to read, in the silent, nearly imperceptible tracks left by his prey, a coherent sequence of events." This, then, is a model of retrospective prophecy, whose distinguishing characteristic lies in "the ability to construct from apparently insignificant experimental data a complex reality that could not be experienced directly" (103).

If Ginzburg's method dates back to man's earliest days as hunter-gatherer, it also contains the embryo of an epistemological model whose slow, "silent emergence" (96) most clearly made itself heard in the closing decades of the nineteenth century. For Ginzburg, the work of the art historian Giovanni Morelli, the detective Sherlock Holmes, and the father of psychoanalysis Sigmund Freud exemplifies a process in which the reading of "infinitesimal traces permit[s] the comprehension of a deeper, otherwise unattainable reality" (101): the semiotic shades into the anatomic in a dialectic of surface and depth which spatializes the interpretative act. The conjectural procedure of these three exemplary cases, he suggests, is underpinned by a cognitive process based, crucially, on the inaccessibility of the object envisaged or narrated. It necessarily proceeds from an always-already absent origin to reconstruct a series of "events that could not be directly experienced by the observer" (103). The conclusions it yields, then, are inevitably speculative interpretations, impossible to verify in moving back along a narrative chain towards a point of grounding in a referent. If the figure of a firmly grounded plot gestures in its most literal sense towards the material concerns of traces left on the surface of a landscape, it also bears on wider questions of narrative anchoring and referentiality. There emerges, in this light, a narratological perspective on the referential underpinning — or, indeed, the lack thereof-of the conjectural paradigm, betokening an absent, or at the very least inaccessible, origin. Absence, born of a lack of grounding or severed referentiality, makes possible the act of narration. ${ }^{\text {ii }}$ 
As a consequence, we might venture, the "truth" of the account of Ginzburg's hunter can only ever be an approximation whose veracity is a function of socially sanctioned plausibility. The conjectural process seeks, as Boris Lyon-Caen has suggested, to "occasionner une reconstitution plausible du vrai" (10). We might, moreover, posit the synonymy of le plausible and le vrai. In the continued absence or inaccessibility of its ultimate referent, the conjectural narrative derives its "truthfulness" not as a function of the object being narrated, but from its success as a narrative technique that demonstrates a relationship of cause and effect between the fragmentary elements that said object leaves in its wake. Faced with an origin that can no longer be interrogated, we move beyond "mere authenticity as a criterion of effective narrative" (Welsh 6) towards power-inflected questions of social approbation and their involvement in the construction and validation of narrative accuracy. For if truth is but a function of plausibility, the success - or perceived truthfulness - of an interpretation derives from the exploitation of socially sanctioned interpretative codes, the appeal to which involves the sustained demonstration of a relationship of causality over mere coincidence. The "moment of triumph" to which Ginzburg refers following the ostensibly accurate description of an animal upon which the hunter has "never laid eyes" (102) testifies, then, to a moment of consensus on the vraisemblance of an explanation. It is the social confirmation of an interpretative paradigm.

This article will suggest that the narratological dimensions of Ginzburg's paradigm inform Balzac's vision of the conspiratorial as it plays out across the narrative topography of Une ténébreuse affaire (1841). Remaining mindful of the risk of reducing Balzac to "Balzac," that reified metonym for a century and its discontents, it will examine the ways in which those familiar Balzacian anxieties bearing on questions of origins and authority overlap with the mechanisms of power underpinning creative and interpretative activity. In this proto-detective novel composed of proliferating plots and counter-plots, conviction is achieved thanks to the damning evidence provided by the indicial and the fragmentary. Testifying to the nineteenth- 
century ascension of evidentiary epistemology identified by Ginzburg, it is from hoof-prints in the mud and traces of plaster that is constructed the comprehensive narrative which ends, for Balzac's royalist conspirators, in another kind of plot, that of the grave dug by "le couperet de la Loi" (VIII, 503). Drawing on the notion of the grounding of plot in its diverse declensions, it will argue that the value of Ginzburg's model for Balzac's "histoire secrète de ce temps" (694) goes far beyond its dependence on a venatic metaphor literalized to the point of ubiquity in the narrative detail of the text.

Amongst the panoply of texts of the vast Balzacian oeuvre, Une ténébreuse affaire remains, for Alain, "un des plus difficiles à lire" (qtd. in Guise 7); "not the most accessible of Balzac's novels" (285), in Gwen Thomas's qualified understatement. We might speculate that it is for this reason that it seems to have fallen within something of a critical blind spot, subject only to an "attention critique sélective" (261), as André Vanoncini notes. If notable mention should be made of Michael Tilby's 2015 article, the revues bibliographiques of L'Année balzacienne nevertheless attest to only six scholarly publications making more than a passing mention of Une ténébreuse affaire since the journal began its third series in 2000. ${ }^{\text {iii }}$ (By way of comparison, the two tales of conspiracy bookending the Balzacian oeuvre, Les Chouans [1829] and L'Envers de l'histoire contemporaire [1848], were over the same period the subject of at least double that number of chapter- or article-length studies.) Indeed, in spite of its oft-cited status as one of the begetters of the detective novel, Une ténébreuse affaire features only in passing in Andrea Goulet's magisterial analyses of the genre's narrative tensions, even as she remarks in her 2006 study upon the apposite nature of its "shadowy title and themes" given the "mysterious textual space of the roman policier" (111). Whilst noting the emphasis that Ginzburg places on the stories of Sherlock Holmes as instantiation of the conjectural method, the present article will concern itself less with the imperfections of Balzac's novel as generic archetype than with its idiosyncratic spatial imaginary and the implications of the surface- 
depth (semiotic-anatomic) model for the question of the conspiratorial as literary motif and narrative mode. Ultimately, we will seek to show, the spatial articulations of the Balzacian landscape of conspiracy point forwards in literary history, not only towards the detective novel in its most developed form, but also towards a proto-Flaubertian aesthetic of the surface.

\section{Secret histories}

In the intra-textual echo chamber of La Comédie humaine, what Balzac terms his "histoire secrète de ce temps" (694) cannot but evoke that oft-quoted scene of Illusions perdues in which the priest Carlos Herrera (alias Vautrin) encounters a suicidal Lucien. "Vous ne me paraissez pas fort en Histoire," says the pseudo-clergyman to the poet. "Il y a deux Histoires: l'Histoire officielle, menteuse, qu'on enseigne, l'Histoire ad usum delphini; puis l'Histoire secrète, où sont les véritables causes des événements" $(\mathrm{V}, 695)$. Cast in the Balzacian "paranoid style,"iv then, true history is secret history. In his guise as conspiracy theorist, opposing an official version of events to a true account shrouded in secrecy, Herrera suggests that the former is a narrative composed ad usum delphini, "for the uses of the Dauphin." The corresponding entry in Larousse's Grand dictionnaire universel du XIX $X^{e}$ siècle tells us that this is a fig-leaf edition of history, a "discours arrangé pour les besoins de la cause, accommodé aux vues d'un parti" (I, 104). This edulcorated, bowdlerized history is a false history, crafted to serve the ends of a particular group and providing a point of convergence for the heterogeneous meanings of the term plot as bearing on the topographic, the narrative and the conspiratorial. ${ }^{\mathrm{v}}$ For Peter Brooks, there may be a "subterranean logic" connecting these meanings; the sense of plot as underhand scheme or conspiracy "nearly always attaches itself to the others: the organizing line of plot is more often than not some scheme or machination, a concerted plan for the establishment of some purpose which goes against the ostensible and dominant legalities of the fictional world" (12). If, as David Bell argues, the nineteenth century displayed an unprecedented faith in "the 
interpretative power of causal explanation, in the potential for using such explanation to decipher the significance of events by revealing hidden sequences of causes leading to them" (1), we might note that Herrera's mendacious version of history, peddled to everyone from the dauphin downwards, relies precisely on the inaccessibility of the hidden "véritables causes" of events. (These, we might presume, are revealed only to a happy few invested in "les besoins de la cause.") The discourse of conspiracy, then, is one born of a missing referent, a cause or origin that can no longer be directly addressed or interrogated. Staging the official as the "true" necessarily proceeds through a manipulation of the categories of causality and coincidence, a need to impose plausibility by accounting convincingly for the causal connections between the fragmentary components of the replacement narrative sequence posited. Deprived of anything in which to truly ground meaning, the "truth" of the official version of history as Herrera tells it is not a function of the events being explained, from which the narrative is inescapably severed, but of the dominant interpretative paradigm and its inevitable ideological colourings. As was the case for Ginzburg's hunter and his partners in conjecture, socially sanctioned plausibility emerges as the only index of veracity.

How, then, to bring these considerations to bear on Balzac's tenebrous emplotment of a series of plots of all political colours? If, for Tilby, Une ténébreuse affaire operates "a radical break from the adventure story with its privileging of plot" (437), this downgrading of novelistic intrigue derives in no small measure from the superposition of a number of politically motivated conspiracies - plots of a different kind. In 1803, the police detectives Corentin and Peyrade arrive in the - somewhat ironically named - département of l'Aube at the request of Malin de Gondreville. The latter is the aptly-monikered republican senator who has acquired the estate from which he derives his new particule as a post-Revolutionary bien national. The Gondreville domain is the ancestral home of the Simeuse family, proscribed émigrés, whose clandestine return prompts the senator to appeal to Fouché, "l'âme du cabinet consulaire" (524) 
if not yet minister of Police. The Simeuse brothers, along with their cousins, the Hauteserres, are conspiring against the life of Bonaparte, incarnating the figure of the factional émigré conspirator operating in the shadows which haunted the post-Revolutionary imagination as "the antithesis of the 1789 ideal of transparent, public politics" (Burrows 150). The renegotiation of the nature and conditions of authority in the post-Revolutionary political and intellectual landscape thus turns the dominant discourse, that "discours ad usum delphini" against which Herrera cautioned Lucien, into something of a counter-discourse. Balzac fictionalizes here the Pichegru-Cadoudal conspiracy of 1804 which, following the failure of the 1800 attentat de la rue Saint-Nicaise, sought to do away with Bonaparte and whisk a royal prince to Paris to prepare a restoration. Indeed, we learn, Malin's loyalties are somewhat less transparent than his ostensibly republican politics might suggest: a mysterious and unlocatable on has offered him the opportunity to "diriger l'action légale de la restauration des Bourbons" (526). The senator is not the only one to play "un jeu double" (524): Michu, the garde-chasse of the Gondreville estate and a man of seemingly impeccable Jacobin credentials, is revealed as staunch counter-revolutionary, the faithful retainer of the redoubtable Laurence de CinqCygne, cousin of the Simeuse twins and sworn enemy of Bonaparte. He is hiding the émigrés in a secret cave at the heart of the estate's forest, having also buried the Simeuse family fortune to protect it from the "spoliateur[s]" (613) of the post-1789 political stage. The cave is a perfect hiding place, and the two policeman are forced to leave empty-handed. To add insult to injury, Laurence, a formidable horsewoman, humiliates Corentin: arriving home to find him clutching the precious box in which, it is revealed, she keeps love letters from the Simeuses, she strikes him with her riding crop.

This apparently minor episode is, in fact, the pivot on which the entire narrative turns. Three years later, "rayés de la liste des émigrés" (596), the Simeuse brothers are peacefully settled with Laurence on the Cinq-Cygne estate when they, the Hauteserres and Michu find 
themselves accused of the kidnapping of Malin, abducted and kept prisoner in the very caveaucachette which previously served as their sanctum. Balzac's recasting of the 1800 abduction of senator Dominique Clément-de-Ris is linked to the royalist counter-revolutionary plot by means of temporal manipulation, leading to the subsequent trial and conviction of the steward and the nobles. The evidence against them turns on the surface traces from which a deeper story is extrapolated: the discovery of hoof-prints, identical to those of their horses, and of traces of plaster, supposedly used to "claquemur[er]" (650) the senator in the secret cave. Michu is sentenced to death, and only the appeal that a humbled Laurence makes in person to her nemesis, now Emperor, saves the life of her cousins, "graciés" (683). The narrative subsequently comes to something of an abrupt end, swiftly dispatching three of the Simeuse and Hauteserre brothers. As soldiers in the Grande Armée, the trio meet the end proleptically figured in their aristocratic family mottoes "cy meurs" and "mourir en chantant" (615). We learn that Adrien d'Hauteserre, "le debris des quatre gentilshommes qu'elle avait vus un moment autour d'elle" (684), survives long enough to accept Laurence's "cœur flétri" and hand in marriage. Upon his death in 1829, “personne n'avait encore pénétré le secret de l'enlèvement du sénateur" (684). The secret history that remains untold is, in Thomas's words, the answer to the following questions: "Who were the five sosies who kidnapped Malin, impersonating the nobles and Michu, even to the latter's red hair and the prints of their horses' shoes? Who are their enemies, and what reason could they have for implicating the innocent?" (288).

The truth is only revealed in an epilogue situated some twenty-five years after the action of the diegesis. At the centre of a salon gathering, Henri de Marsay-one of Balzac's most privileged narratorial figures-recounts a secret meeting in 1800 between Fouché, Talleyrand, Sieyès, Carnot and Malin, on the eve of the battle of Marengo. A coup is planned, to be carried out if Bonaparte's Italian campaign fails. Recasting to their own ends the narrative of the coup d'etat which brought their target to power, the conspirators conclude: "Notre Dix- 
huit Brumaire doit être prêt" (691). Malin is tasked by the "génie ténébreux" (692) that is Fouché with the production and dissemination of the documents proclaiming the advent of the new government in the event of Bonaparte's defeat. When the news of victory reaches the conspirators, Malin, "sur qui toute la responsabilité du complot pouvait tomber, fut si effrayé, qu'il mit les ballots dans des charrettes et les mena nuitamment à Gondreville, où sans doute il enterra ces sinistres papiers dans les caves du château" (693). If de Marsay's equivocating "sans doute" seems to at least partially give the lie to the Balzacian fantasy of historical mastery through seamless emplotment, he is nonetheless staged as expert storyteller who has "admirablement peint" (689) the intricacies of the scene.

And yet, by the end of de Marsay's putative explanation, the reader is none the wiser as to the "le secret de l'affaire": peindre is to cover over as much as to depict, and de Marsay's tale of the abortive coup and its aftershock refers only to the political dimensions of the affaire. Rastignac, a fellow salon invitee, comments as much: "Mais [...] je ne vois pas dans tout ceci Mme de Cinq-Cygne" (695). De Marsay supplements his story in a sweeping, breathless paragraph, "a kind of afterthought" (Thomas 294) which effectively serves to devalorize the lengthy narrative that precedes it. In 1806, when domestic politics are ostensibly less volatile, Fouché, "tout en cachant la main qui remuait les cendres de ce foyer" (692), sends Corentin to recover the incriminating documents:

[L]es cinq inconnus étaient des escogriffes de la Police générale de l'Empire, chargés d'anéantir des ballots d'imprimés que le comte de Gondreville était venu précisément brûler en croyant l'Empire affermi [. . .] Mais, dans cette épouvantable affaire, il y a eu de la passion de la part de l'agent principal, qui vit encore, un de ces grands hommes subalternes qu'on ne remplace jamais, et qui s'est fait remarquer par des tours de force 
étonnants. Il paraît que mademoiselle de Cinq-Cygne l'avait maltraité quand il était venu pour arrêter les Simeuse. (695)

The abortive royalist conspiracy is thus neutralized and superseded by a shadowy counter-plot masterminded by the formidable Fouché, itself looking back to the Urplot of the early days of the Consulate. Corentin, "l'agent principal," uses his orders as the pretext to avenge Laurence's slight: Corentin hired the sosies and fabricated the incriminating letter that damns the nobles and Michu at their trial. This strategy, we might note, served him well in Les Chouans —as, in a signposting of Balzacian intratextuality, he reminds us in his oblique reference to Marie de Verneuil: 'J'en ai fait crever une qui la valait bien, et qui m'avait par trop échauffé la bile! Si elle [Laurence] retombe sous ma coupe, je lui paierai son coup de cravache" (590). The kidnapping of Malin, then, is tangential to the political machinations, and the spheres of public and private motivation overlap to bewildering effect. Set against the high stakes of high politics, such "petty motivation" (Tilby 427) cannot but cast an ironic shadow over the plot and the plots it narrativizes in relation to their assumed significance as subject matter. We might ask, with Julien Sorel, “n'est-ce que ça?” (Stendhal 148). If, as Marx would have it, history repeats itself, the first time as tragedy and the second time as farce, the "passion" (695) with which Corentin plots to have Marie betray Montauran is desublimated in the risible motives underpinning the considerable efforts he deploys to frame Laurence and her cousins.

An epilogue that looks back to a point outside narrative time, a devalorization of plot in relation to its presumed importance, a difficulty in squaring action with motivation-such features would seem to align Une ténébreuse affaire less with the commonplaces of Balzacian realism than with the sense of uncertainty pervading the novel in its later, Flaubertian guise. If Balzac's bewildering superposition of plots and counter-plots undermines the possibility of coherent emplotment and perhaps even the notion of plot itself (Tilby 426), Une ténébreuse 
affaire is less un livre sur rien than a book in which nothing makes sense, or rather makes too much sense, incessantly over-signifying. Where a certain version of literary history would reserve aesthetic modernity in the nineteenth-century novel for the hermit of Croisset and he alone, the self-questioning narrative voice of Une ténébreuse affaire undermines the Balzacian pretention to the "interpretative mastery" (Miller 29) of minutiae whose legibility is the hallmark of the readerly text. Beyond the conventions of the detective novel and its recourse to semiotic red herrings, the novel testifies to a more radical sense of unintelligibility that undercuts the certainties of the famous Balzacian hermeneutic imperative, the systematic and systematizing drive to "surprendre le sens caché dans cet immense assemblage de figures, de passions et d'événements" (I, 11). Bespeaking an anxiety concerning the continued validity of the spatial dialectic of the semiotic and the anatomic germane to both Herrera's conspiratorial secret history and Ginzburg's conjectural paradigm, Une ténébreuse affaire enacts a cognitive crisis born of the post-Revolutionary experience of history and the changes it entails in the way plots are consumed and constructed.

\section{Man-hunts and treasure hunts}

In light of our concern with the Ginzburgian model and its venatic metaphoricity, we might note that hunting is the raison d'être of the Gondreville domain. Built by a wealthy marquis "uniquement pour se faire une belle chasse" (504), these grounds are a "magnifique théâtre" (503) that provides the stage for a man-hunt far more sinister than the pre-Revolutionary pursuits of the titled nobility. Hunting is the cherished pastime of the novel's protagonists, most notably the redoubtable Laurence, whose "adresse à la chasse tenait du miracle." Likened to Diana Vernon, Walter Scott's "chasseresse ecossaise" (536), we learn that she is able to "mani[er] un pistolet, un fusil, avec la vigueur d'un chasseur exercé" (537). The elder Hauteserre brother, Robert, is also a "grand chasseur" (602), with all of the nobles finding "une 
distraction violente dans les plaisirs de la chasse, qui, en fatiguant excessivement le corps, ôtent à l'âme les occasions de voyager dans les steppes si dangereux de la rêverie" (608). If this "rêverie" translates into the "rage froide et calculée" applied in the services of "la conspiration des hommes qui tentèrent de retourner le 18 brumaire contre le Premier consul," the "haine" of Bonaparte is not the only thing "commune" (538) to the plotters. A "passion pour la chasse" (549) would also appear to transcend divisions of social status: our first encounter with Michu, for example, finds him "vêtu d'une veste de chasse en coutil vert," cleaning a rifle "avec le soin que mettent à cette occupation les chasseurs adroits." It is, moreover, through appeal to the hunting motif that we learn that all at Gondreville is perhaps not as it seems: the narrator observes that, despite his outfit, "cet homme [Michu] n'avait ni carnier, ni gibier, enfin aucun des agrès qui annoncent ou le départ ou le retour de la chasse." With casual recourse to an adverb that serves as much to emphasize the stratification of knowledge of the world of the diegesis as it does to incite the reader's hermeneutic drive, the narrator comments: “évidemment un chasseur ne prend pas de si minutieuses précautions pour tuer le gibier et n'emploie pas, dans le département de l'Aube, une lourde carabine rayée" (502). Encoding Michu's counter-revolutionary secret from the novel's opening pages, posing the question of what novelistic discourse can take in in order to take in the reader, the Balzacian narrator thus casts hunting in a more sinister guise, concretized in the "chasse à l'homme" in which the police detectives Corentin and Peyrade, "deux limiers à la piste de faits inconnus et cachés" (579), are said to be engaged. To this end, in a politicization of the reconstitutive practice of Ginzburg's hunter:

L'homme de police a toutes les émotions du chasseur; mais en déployant les forces du corps et de l'intelligence, là où l'un cherche à tuer un lièvre, une perdrix ou un chevreuil, il s'agit pour l'autre de sauver l'État ou le prince, de gagner une large 
gratification. Ainsi la chasse à l'homme est supérieure à l'autre chasse de toute la distance qui existe entre les hommes et les animaux. D'ailleurs, l'espion a besoin d'élever son rôle à toute la grandeur et à l'importance des intérêts auxquels il se dévoue. Sans tremper dans ce métier, chacun peut donc concevoir que l'âme y dépense autant de passion que le chasseur en met à poursuivre le gibier. (578-79)

The most significant role of the hunting motif, however, is its status as the subject of statements of equivocal meaning. Made in jest, these utterances are turned against the nobles to frame them for the kidnapping of the republican senator that provides the thematic crux of the novel. Michu explains to Laurence that he has “joué le rôle d'un Jacobin enragé, pour rendre service à mes jeunes maîtres"; he is, "à l'insu de messieurs de Simeuse, le gardien de leur fortune" (562). The nobles' faithful retainer has secretly buried this fortune in the Nodesme forest that borders the Gondreville estate. They accordingly set out to dig up their gold, using the pretext of a hunting expedition as cover. They soon encounter the farmer Beauvisage, who, having asked "vous allez donc à la chasse, malgré les arrêtés de prefecture?", reminds them that, "si vous avez des amis, vous avez aussi des ennemis" (619). Their worst enemy proves to be one of their own, as one young aristocrat innocently utters "le mot qui [les] perd tous" (644), “ces paroles [...] auxquelles l'événement donna un tout autre sens": "Dieu veuille que notre chasse réussisse, et tu retrouveras tes maîtres!" That this "fatale parole" (619) is referring to a treasure hunt later makes little difference to the court.

In the novel's dialectic of exposure and concealment, the Gondreville estate as landscape of conspiracy proves to be both friend and foe. If the venatic motif is omnipresent, the truly privileged figure of the narrative is the secret cave at the heart of the forest, known only to Michu by virtue of its strategic location where "les chasseurs n'avaient jamais visité, fouillé ni sondé" (565). A space at the centre of the story that serves as both shelter to the 
émigrés and prison to the kidnapped senator, it is a sign without value, ready to have meaning projected onto it. Similarly, if the thick trees dissemble both the buried fortune and this multivalent cachot-cachette, the soft earth of the forest floor also betrays the hoof-prints that lead to the conviction of the nobles and their loyal factotum: "nous reconnaitrons," says Peyrade, “à l'empreinte des pieds, quels sont les êtres qui ont passé [sic] par là" (572). In discussion with Laurence, the defence lawyer Grandville, "pour qui une machination quelconque devenait évidente" (670), remarks that "tout dépend des débats devant une cour criminelle, et les débats rouleront sur de petites choses que vous verrez devenir immenses" (647). Remaining mindful of the optic of Ginzburg's paradigm, we should note the emphasis placed on the weaknesses of the semiotic model, the possibility of reading surface traces to reconstruct the deeper, lost story of these "petites choses": the aristocrats are caught in a trap when, unable to account for their movements in admitting that their hunting expedition was in pursuit of the buried treasure, the hoof-prints of their horses are imitated by five sosies. As Peyrade comments to Michu: "regardez les fers de vos chevaux, et vous verrez que vous vous êtes trahis vous-mêmes" (599). By virtue of its materiality, then, the surface of the landscape is subject to semiotic manipulation: set against and inscribed upon the Balzacian landscape of conspiracy, Corentin's plot is all too well-grounded in the most literal sense of the term.

\section{Plaster and platitude}

If the necessities of emplotment subtending the criminal trial bear on the semantic multiplicity of framing as persecutory activity and narrative control, Michu's final encounter with "le couperet de la Loi" (503) suggests that the narrative manipulation made possible by the compromised referentiality of a poorly grounded plot can be applied in the service of more sinister, inculpatory, and conspiratorial designs. What, then, might this possibility of semiotic manipulation imply for the familiar Balzacian incitement to read "symptomatically,"vi moving, 
as "archéologue du mobilier social" (I, 11), from surface appearance to that deeper, hidden truth in which one might find the secret history?

For Lyon-Caen, "la dialectique de la surface et de la profondeur, fût-elle fondée sur une simple pellicule, est essentielle à l'herméneutique balzacienne" (27). In the textual universe of La Comédie humaine, he adds, "la surface du monde [. . .] est tout à la fois un tissu d'apparences à déchiffrer et une réserve d'essences à retrouver" (8). In a happy convergence with our own interest in Ginzburg's model, Balzac's magnum opus is, in this way, "inséparable [...] des pratiques scientifiques et culturelles ayant fécondé, dans la première moitié du siècle, le paradigme indiciaire" (10). Sustained engagement with Une ténébreuse affaire is, however, notably absent from Lyon-Caen's analysis of the relationship between meaning and matter in the Balzacian text. If the importance he accords to the notion of the surface is salutary, his neglect of this novel is all the more surprising in light of his (welcome) suggestion that "l'inflexion du statut accordé aux surfaces et aux corps sensibles doit être réinscrite dans l'histoire littéraire du réalisme au dix-neuvième siècle" (146). With this in mind, we might note that the second strand of evidence put forward against the counter-revolutionary conspirators is the traces of plaster left on Michu's clothes, those "habits [qui] faisaient partie des pièces à conviction" (655). The plaster is, in reality, used as a security measure to "murer le caveau" (631) in which the Simeuse brothers' recently unearthed treasure is hidden. Deploying the term conviction along the semantic axes of the narrative and the judicial, the prosecution emplots a version of events in which this plaster is to have served to "claquemur[er]" (663) the missing senator, "scellé [. . .] avec des pierres et du plâtre" (664). The figure of plaster reveals itself as the nexus of a tension between surface (semiotic) and depth (anatomic) models of reading, gesturing towards an alternative version of literary history in which the Balzacian text adumbrates what Lyon-Caen terms "l'écriture flaubertienne de la surface" (147). 
In his analysis of the spatial logic and architectural metaphoricity of nineteenth-century France, Philippe Hamon aligns a post-1848 “avènement d'un règne de la non-épaisseur” with "des désillusions d'ordre politique" (145). Set against the Romantic world of lapidary inscriptions and a vision which sought to "voir dans les choses plus que les choses" (Hugo 265), the widespread use of plate and plaster at the mid-century testifies, for Hamon, to the “intrusion d'une modernité illisible dans le cadre bâti" (128). In an unease foreshadowing what Walter Benjamin would later theorize as the lost "auratic" quality of the mechanically reproduced work of art, plaster as ersatz stone, "plaquage mensonger et masquage des façades," became, Hamon argues, a "thématique et métaphorique littéraires obsédantes" (137). If plaster throws something of a spanner in the smooth workings of a Balzacian physiognomic discourse that would seek to seamlessly align surface appearance and deeper truth, what is at stake is not merely a semiotics and an aesthetics, but also an ethics. How to distinguish between real and fake, copy and original? Plaster emerges as the privileged medium for the inscription-the emplotment, we might venture — of a narrative of falsehood or a false narrative, as Laurence and her co-conspirators come to know only too well.

The interest of this wider nineteenth-century discourse on plaster for our purposes goes beyond a mere rehearsal of the tropes of the familiar Balzacian anxieties concerning the legibility of the façade. In Splendeurs et misères des courtisanes (1838-47), Corentin is revealed to be moonlighting as a private detective, with the reader given privileged insight into his living quarters:

Le logement de Corentin n'était connu que du Directeur-Général de la Police du Royaume et de Peyrade [. . .] Dans cette chambre sans aucune apparence se tramèrent des plans, se prirent des résolutions qui fourniraient d'étranges annales et des drames curieux, si les murs pouvaient parler. (VI, 537) 
If Balzac's narrator expresses regret that Corentin's walls cannot speak, the surfaces of Une ténébreuse affaire, which he conspiratorially manipulates, speak, or at least signify, all too much. The use of traces of plaster as one of the prosecution's pièces à conviction against Michu and the nobles, then, returns us to the familiar play between the semiotic and the anatomic, gesturing towards the spatialization of the secret that we brought out in relation to Herrera's secret history. If plaster comes to be aligned with a loss of origin, a missing referent, it is precisely this absence that opens up the space of conspiratorial speculation within which Corentin positions himself with such expertise. Balzac's prosecution has recourse to the material in their emplotment of a smooth narrative of the nobles' culpability-to such an extent that 'les plaisants de la ville dirent qu'on avait replâtré l'affaire, que l'Accusateur public avait gâché sa position, et que les Simeuse devenaient blancs comme plâtre” (VIII, 659).

It is, then, by virtue of Grandville's "petites choses" that is constructed a false, inculpatory narrative: the purported plot to kidnap Malin is emplotted with fatal consequences. There is a questioning of the indicial relation, a discord between the manifest signs of the horses' prints, the traces of plaster and the false vérité of the story of the nobles' guilt towards which they point. If, for Umberto Eco, "semiotics is in principle the discipline studying everything which can be used in order to lie" (7), this statement is unleashed in full force across the narrative landscape of Une ténébreuse affaire. The deceptive surface of the falsified "précieuses empreintes" (150) points, supposedly, to a deeper truth, located, crucially, beyond the reach of the untrained eye: "ils auront tué le sénateur et l'auront plâtré dans quelque muraille" (636). For Hamon, the plastered surface can be aligned with two hermeneutic axes, either the excess of a "hypertrophie sémiotique" or the lack of a "non-signification radicale" (128). The cave at the heart of the forest is invested, respectively, with too much meaning for the prosecution and not enough for the accused, the latter situation bespeaking a total absence 
of understanding not so far removed from that of the reader, even after de Marsay's putative clarification. The fragmentary traces left on the landscape are subsumed into a conspiratorial totality of scapegoating. In a post-Revolutionary world in which "royaliste [. . .] veut dire brigand" (644), we bear witness to the "injuste condamnation" of "cinq victimes d'un horrible complot" (672). As the lawyer Bordin explains the predicament in which Michu and the nobles find themselves:

Si, par malheur, vous disiez être allé chercher onze cent mille francs d'or dans la forêt, vous enverriez tous les accusés aux galères comme voleurs. Accusateur public, jurés, juges, audience, et la France croiraient que vous avez pris cet or à Gondreville, et que vous avez séquestré le sénateur pour faire votre coup. En admettant l'accusation telle qu'elle est en ce moment, l'affaire n'est pas claire; mais, dans sa vérité pure, elle deviendrait limpide; les jurés expliqueraient par le vol toutes les parties ténébreuses, car royaliste aujourd'hui veut dire brigand! (644)

They are, as Grandville cries in despair, "le jouet d'une puissance inconnue et machiavélique" (671). Faced with the impossibility of showing either "le corps du délit" (663) of the missing senator or "[le]s cachettes, le plan de la forêt, les tuyaux de fer-blanc, l'or pour justifier l'emploi de [la] journée" (645), the nobles and Michu are deprived of a point of origin in which to ground their story. The referents of the competing versions of events - the buried fortune and the kidnapped senator - are manifestly absent: there is an interpretative gap at the centre of the story that mirrors the cave at the centre of the forest. The possibility of a quasi-tactile narrative manipulation comes to the fore as the prosecution "mass[e] les preuves, les semipreuves, les probabilités" (663). The narrative of their innocence is thus undermined by its severed referentiality, overshadowed by the literally grounded plot etched on the surface of the 
landscape. It proves impossible to demonstrate that the relationship between the hoof-prints, the plaster, the nobles' outing and the kidnapped senator is but a coincidence when a causal account appears so much more vraisemblable. In the politico-historical context of a postRevolutionary society in which "royaliste [. . .] veut dire brigand," the story of the kidnapping of a republican senator by resentful counter-revolutionary conspirators enjoys a degree of plausibility superior to any alternative version of events. If "le devoir de la Défense est [. . . ] d'opposer un roman probable au roman improbable de l'Accusation' (656), the prosecution's task is an imposition of an interpretation ad usum delphini, with, the "discours arrangé pour les besoins de la cause" that of the synonymy of "royaliste" and "brigand" that underpins the story of the nobles' guilt. The tenebrous hermeneutic depths, then, are but an empty space, ready to have a meaning imposed upon them.

In its invitation to read "symptomatically," seizing on surface detail to move towards those all-important "faits inconnus et cachés" (579), the Balzacian text takes meaning and form in the épistèmè de la profondeur that, for Michel Foucault, appears at the end of the eighteenth century. This, he suggests is a new, post-Classical epistemology which seeks to "rapporter le visible à l'invisible, comme à sa raison profonde, puis remonter de cette secrète architecture vers les signes manifestes qui en sont donnés à la surface des corps" (Foucault 142). But does this really hold for Une ténébreuse affaire, where Foucault's secret architecture is made literal in the central image of the underground cave, the empty space where depth should have been? Does the emphasis placed on the problematic materiality of the surface (be it plaster or the soft earth of the forest) not, rather, point towards, if not a complete lack of depth, at the very least a false profundity? Indeed, the "oeuvre archéologique" in which Michu engages in order to find the cave that serves as the novel's master-figure comes to fruition when "il sentit le terrain sonner le creux" (565). This surface à fausse profondeur thematizes a figure of the novel's own structure, signalling a misleading surface against which, to recast an expression made in 
reference to Laurence, "le vide ressemble à de la profondeur" (537). By virtue of its materiality, the surface of the conspiratorial landscape of Une ténébreuse affaire is subject to semiotic manipulation, framing a narrative of false depth that both frustrates the hermeneutic drive and points forward in literary history towards the Flaubertian aesthetic of platitude, that ironic emptying-out of meaning born of a citational poetics. Une ténébreuse affaire, then, would seem to work in opposition to the idée recue of an incorrigible Balzacian investment in the unearthing of a stable, underground secret history to be captured and represented in language. This critical doxa, we might note, is inevitably expressed via a metaphorics of surface and depth. Barthes, in this vein, writes of Balzac that "toute une partie du réel lui échappe: précisément sa surface" (550), whilst, for Alain Robbe-Grillet, the epistemological naivety of the Balzacian project - in opposition to which he defines le nouveau roman-derives largely from its investment in "[1]es vieux mythes de la "profondeur," that quest for the "âme cachée des choses" undertaken by the writer as "vaillant[] spéléologue[]" (22).

Even more sympathetic critics have recourse to this semantic field. In his study of Balzac and Henry James, Brooks, for example, writes of the "pressure of the prose" that must uncover the Frenchman's true subject, "hidden and masked" (5), unearthing a realm of meaning which cannot be accessed without "the 'pressure' applied to the surfaces of the real, the insistence of the recording glance" (125). And yet, as we have sought to show, the conspiratorial narrative of Une ténébreuse affaire works against the grain of the meta-critical narrative that Claude Burgelin memorably terms la Flaubertolâtrie. The novel testifies to a peculiarly Balzacian form of aesthetic modernity stemming not from a proto-postmodernist pleasure in the unfettered play of the signifier, but from an anxiety born of the impossibility of truly grounding discourse, of anchoring novelistic truth in a stable referent. The conspiratorial reveals itself as a particularly fertile field in which to explore this semantic and semiotic paranoia. It is not, then, pace Barthes, post-1848 or "à partir de Flaubert [. . .] [que] s'instaure 
l'ère du soupçon" (Burgelin 10), but, rather, somewhat earlier, as we have sought to demonstrate in sketching the contours of a poetics of conspiracy. In consideration of how literary poetics might be brought to bear on the history of ideologies, conspiracy as fact or event becomes less significant than the conspiratorial as narrative mode that generates its own "alternative facts" according to the historical agents involved. For, as Balzac's narrator comments, in a phrasing which speaks just as well to the credo of the realist author, "si, en justice, la vérité ressemble souvent à une fable, la fable ressemble aussi beaucoup à la vérité" (657). Confronted with the fragmentary epistemologies of Une ténébreuse affaire's crisis of plot (emplotment) born of a crisis of plotting (conspiracy), we as readers cling ever more tightly to the idea of the centre of a narrative as stable locus of truth, that place of the secret as a "place of ultimate knowing at which the writing would come to rest" (Lock 879). And yet, with Une ténébreuse affaire and its master-figure of the caveau-cachette-cachot, we find that, as Geoffrey Hartman writes of the mystery story, "the centre [it] scan[s] is an absence; the darkness [it] illumine[s] has no heart [. . . Instead of a whodunit we get a whodonut, a story with a hole in it" (166). .ii $^{\text {.i }}$

St John's College

University of Cambridge

\section{NOTES}

i The French translation, le paradigme cynégétique, adheres more closely to the venatic metaphoricity of Ginzburg's model. The original, Italian version of the essay appeared in 1986 as "Spie: radici di un paradigma indiziario."

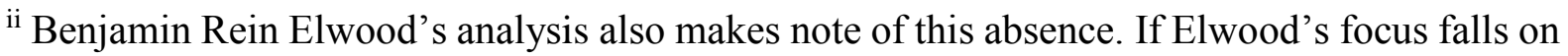
the figure of conspiracy as imposed interpretation, my own project accords equal emphasis to 
the manner in which conspiratorial speculation may function as what Richard Terdiman, in his study of a post-1848 aesthetics of oppositionality, terms a "counter-discourse."

iii These were: Alexandre (2015), Ebguy (2012), Marinčič (2005), Tilby (2015), Vanoncini (2016), and Watts (2014). We might also note Owen Heathcote's discussion of the relationship between space, violence and representation in Une ténébreuse affaire in his 2009 monograph (101-24). This chapter develops the concerns adumbrated in "Balzac at the Crossroads: The Emplotment of Terror in Une ténébreuse affaire," Heathcote's earlier contribution to a collective volume (Booker and Pasco 130-46) unusual by virtue of its inclusion of a second article concerned with the same, little-studied novel, Armine Kotin Mortimer's "Balzac: Tenebrous Affairs and Necessary Explications" (242-55). The previous two decades saw the publication of only a handful of other article-length studies of Une ténébreuse affaire: Courteix (1998), Labouret (1990), Schuerewegen (1990), Taylor (1986), and Thomas (1994).

iv I borrow this term from Richard Hofstadter's 1964 essay, “The Paranoid Style in American Politics." For Hofstadter, "the distinguishing thing about the paranoid style is not that its exponents see conspiracies or plots here and there in history, but that they regard a 'vast' or 'gigantic' conspiracy as the motive force in historical events. History is a conspiracy [. . .]" (29, original emphasis).

${ }^{v}$ In his discussion of the semantic range of the word, Peter Brooks helpfully delineates the following categories: "1. (a) A small piece of ground, generally used for a specific purpose. (b) A measured area of land; lot. 2. A ground plan, as for a building; chart; diagram. 3. The series of events consisting of an outline of the action of a narrative or drama. 4. A secret plan to accomplish a hostile or illegal purpose; scheme" (Reading for the Plot, 11-12).

vi On the respective merits of "surface" and "symptomatic" reading, see Stephen Best and Sharon Marcus's introduction to their edited special number of Representations. Rita Felski's 
recent study also challenges the critical sensibility of a "hermeneutics of suspicion" to make a case for what she terms "postcritical reading."

vii I am indebted to Elwood's analysis for drawing my attention to the importance of this observation.

\section{WORKS CITED}

Alexandre, Didier. "Claudel et Balzac: une ténébreuse affaire.” L'Année balzacienne 3rd ser. 16 (2015): 169-98.

Balzac. La Comédie humaine. Ed. Pierre-Georges Castex. Gallimard, "Bibliothèque de la Pléiade," 1976-81. 12 vols.

---. Une ténébreuse affaire. Ed. René Guise. Gallimard, 1973.

Barthes, Roland. "Nouveaux problèmes du réalisme." Euvres completes. Ed. Éric Marty. Vol. 1. Seuil, 2002. 549-51.

Bell, David F. Circumstances: Chance in the Literary Text. U of Nebraska P, 1993.

Best, Stephen and Sharon Marcus. "Surface Reading: An Introduction." Representations 108 (Fall 2009): 1-21.

Booker, John T., and Allan H. Pasco, eds. The Play of Terror in Nineteenth-Century France. U of Delaware P, 1997.

Brooks, Peter. Reading for the Plot: Design and Intention in Narrative, new edn. Harvard UP, 1992.

---. The Melodramatic Imagination: Balzac, Henry James and the Mode of Excess. Yale UP, 1976.

Burgelin, Claude. "La Flaubertolâtrie.” Littérature 15 (October 1974): 5-16. 
Burrows, Simon. "The émigrés and conspiracy in the French Revolution, 1789-99." Conspiracy in the French Revolution. Ed. Thomas E. Kaiser, Marisa Linton and Peter R. Campbell. Manchester UP, 2007. 150-71.

Courteix, René-Alexandre. "La Vision de l'Église catholique dans Une Ténébreuse affaire." L’Année balzacienne 2nd ser. 19 (1998): 29-38.

Ebguy, Jacques-David. “Une ténébreuse affaire, un roman politique? Souveraineté, société et dissensus.” Les Fables du politique des Lumières à nos jours. Ed. Éléonore Reverzy, Romuald Fonkoua and Pierre Hartmann. PU de Strasbourg, 2012. 81-98.

Eco, Umberto. A Theory of Semiotics, new edn. Indiana UP, 1979.

Elwood, Benjamin Rein. "Secret Histories: Narratives of Conspiracy in Balzac and Zola" (unpublished doctoral dissertation). Yale University, 1996.

Felski, Rita. The Limits of Critique. U of Chicago P, 2015.

Foucault, Michel. Les Mots et les choses: une archéologie des sciences humaines. Gallimard, 1966.

Ginzburg, Carlo. "Clues: Roots of an Evidential Paradigm." Clues, Myths and the Historical Method. Trans. John and Anne C. Tedeschi. Johns Hopkins UP, 1989. 96-125.

---. "Spie: radici di un paradigma indiziario." Miti, emblemi, spie: morfologia e storia. Einaudi, 1986. 158-93.

Goulet, Andrea. Optiques: The Science of the Eye and the Birth of Modern French Fiction. U of Pennsylvania P, 2006.

Hamon, Philippe. Expositions: littérature et architecture au XIX siècle. José Corti, 1989.

Hartman, Geoffrey. "Literature High and Low: The Case of the Mystery Story." The Geoffrey Hartman Reader. Ed. Geoffrey Hartman and Daniel T. O’Hara. Edinburgh UP, 2004. 164-79. Heathcote, Owen. Balzac and Violence: Representing History, Space, Sexuality and Death in “La Comédie Humaine”. Peter Lang, 2009. 
Hofstadter, Richard J. The Paranoid Style in American Politics and Other Essays, new edn. Harvard UP, 1996.

Hugo, Victor. “Odes et ballades. Préface de 1822.” Euvres poétiques. Ed. Pierre Albouy. Vol. 1. Gallimard, "Bibliothèque de la Pléiade," 1964. 265.

Labouret, Mireille. "Le Sublime de la Terreur dans Les Chouans et Une ténébreuse affaire." L’Année balzacienne 2nd ser. 11 (1990): 317-27.

Larousse, Pierre. Grand dictionnaire universel du XIXe siècle. Larousse et Boyer, 1867-90. 17 vols.

Lock, Peter. “Text Crypt.” MLN 97.4 (May 1982): 872-89.

Lyon-Caen, Boris. Balzac et la comédie des signes: essai sur une expérience de pensée. PU de Vincennes, 2006.

Marinčič, Katarina. "Reportage d'un événement quasi-historique: Une ténébreuse affaire de Balzac." Le Sens de l'événement dans la littérature française des XIX et XX $X^{e}$ siècles. Ed. Pierre Glaudes and Helmut Meter. Peter Lang, 2005. 15-24.

Miller, D.A. The Novel and the Police. Berkeley, U of California P, 1988.

Robbe-Grillet, Alain. Pour un nouveau roman. Éditions de Minuit, 1961.

Schuerewegen, Franc. "Une ténébreuse affaire ou l'histoire et le jeu." L'Année balzacienne 2nd ser. 11 (1990): 375-88.

Stendhal. Le Rouge et le noir. Ed. Anne-Marie Meininger. Gallimard, 2000.

Taylor, Françoise M. "Mythe des origines et société dans Une Ténébreuse affaire de Balzac." Nineteenth-Century French Studies 14.1-2 (1985): 1-18.

Terdiman, Richard. Discourse/Counter-Discourse: The Theory and Practice of Resistance in Nineteenth-Century France. Cornell UP, 1985.

Tilby, Michael, "Plotting and the Novel: The Duplicity of Espionage in Balzac's Une ténébreuse affaire." Modern Language Review 110.2 (April 2015): 422-37. 
Thomas, Gwen. “The Case of the Missing Detective: Balzac's Une ténébreuse affaire." French Studies 48.3 (July 1994): 285-98.

Vanoncini, André. "Balzac et la ténébreuse naissance du roman policier.” Romanische Studien 3 (March 2016): 261-73.

Watts, Andrew. "An Overwritten Mystery: Balzac, Television, and Une ténébreuse affaire." Rewriting Wrongs: Detective Fiction and the Palimpsest. Ed. Angela Kimyongür and Amy Wigelsworth. Cambridge Scholars Publishing, 2014. 95-110.

Welsh, Alexander. Strong Representations: Narrative and Circumstantial Evidence in England. Johns Hopkins UP, 1992. 